Original article

\title{
Cardiac War Wounds
}

\author{
Slavko Ždrale, Marko Vuković \\ Surgical Clinic, Clinical Center East Sarajevo, Bosnia and Hercegovina
}

\begin{abstract}
SUMMARY
The paper presents myocardial contusion and penetrating cardiac war wounds. The authors report their experience with thirteen cases of penetrating wounds, out of which only two were treated in the conditions acceptable for surgery. The other 11 wounds were treated in war hospitals which were mostly improvised, and in mobile surgical teams. The basic, exclusively physical examination methods are described here, with the emphasis that "it is better to open and see than wait and see". Such procedure gave the results that could be compared with the best ones in the literature (only one death). Three, conditionally speaking, specific cases are presented: one tangential wound with relapsing hemorrhage and two spontaneously sanitized ventricle wounds followed by other kinds of complications.
\end{abstract}

Key words: cardiac war wounds, pericardial tamponade, urgent intervention 


\section{INTRODUCTION}

The exact number of cardiac wounds in the total number of war wounds is unknown. The first wound was described by Ambroise Paree in the $16^{\text {th }}$ century. In 1679, Riolanes suggested the pericardial centesis procedure, which was carried out by Larrey in 1829. The first cardiac wound was sutured by Williams (1) in 1898 , only 10 years after the famous Billroth's statement that one who tries to suture a heart wound will experience the contempt of his colleague because sewing is "the prostitution" of surgery.

Cardiac wounds are not described often enough, not even nowadays, and that happens for one simple reason: most of the patients do not live long enough to reach a doctor. Nevertheless, due to the proximity of hospitals in some big cities, dozens of patients with cardiac wounds, mostly with penetrating trauma, are admitted (1).

Blunt cardiac injury is mostly sustained in car accidents when due to a sudden deceleration the heart hits the frontal wall of the thorax. With a speed of 100 $\mathrm{km} / \mathrm{h}$, the energy of the heart which hits the thoracic bone amounts to $34 \mathrm{~kg}$ (2). The other mechanism of a blunt cardiac injury is the compression of the heart, which is an incompressible organ, between the two firm osseous masses (spinal column and thoracic bone). These kinds of wounds happen both in wartime and peacetime.

Patel (3) wrote that in thoracic wounds, cardiac wounds cause $1 / 5$ of sudden deaths. The heart is at extreme risk of injuries which cause the anterior flail chest, fracture of the upper ribs on both sides and the anterolateral left-sided flail chest.

Penetrating cardiac wounds inflicted at the peacetime are mostly caused by blunt objects, in rare cases by guns, while in wartime they are mostly caused by guns, or even more often by pieces of explosive devices, secondary projectiles, and exceptionally by pieces of ribs.

More than $70 \%$ of patients die before they even reach hospital. Such patients probably have wounds with large apertures in heart cavities (4).

Diagnostics of cardiac wounds caused by blunt force is complicated. Information about the wound which could be inflicted on the heart is a valuable fact for the further course of wound management. Anatomically speaking, those are contusions of the heart muscle in one or more places, with different size, rupture of the heart valves and papillary muscles. The authors saw in the autopsy report the contusion focal point which affected the entire anterior side of the heart as well as the entire bulk of its wall. These wounds often cause deaths in polytrauma patients. Subjective discomforts are: fear of immediate death, suffocation, stenocardia, etc. Objective discomforts are: arrhythmia caused by tachycardia, tachyarrhythmia and absolute arrhythmia, low arterial and high venous pressure, cyanosis, etc. ECG of abnormalities corresponds to acute myocarditis, fibrillation of ventricles and atriums, blocks branches of mostly right, changed ST segment. If possible to be carried out, echocardiography is useful. It easily discovers the hemorrhage and when controlled, it can help carrying out perycardiocentesis. Normally, in war conditions, it is difficult to perform it, plus it will delay the intervention time, so it is not recommendable for the most difficult (the most urgent) cases.

Increased enzymes are present depending on the size of the contusion focus, however, in war conditions, they are insignificant. Thus, they are more important during the monitoring of the patient's condition during the treatment (1).

Clinical presentation of penetrating heart wounds is extremely dramatic. Clinical signs and their evolution mostly depend on the speed of blood coagulation in the pericardium, and partly on the associated wounds.

Open heart cavities always cause pericardial hemorrhage, the speed of which depends on the size of the pressure in cavities. More than $150 \mathrm{ccm}$ of blood fills the pericardium which extends just a bit due to the firm wall of the heart. That leads to increased pressure in the pericardium which then leads to aggravated function of large veins and atriums. The pressure compresses veins and atriums and causes slow heart's filling, thus the heart works "idly". If a patient has not bled out, then the neck veins are swollen. This entire syndrome is called the pericardial tamponade. It happens in $70-80 \%$ of heart cavities, and in $20-30 \%$ of bleedings (5).

The wounded people experience terrible fear of immediate death, suffocation and loss of consciousness. Objectively speaking, there are cyanosis, swollen neck veins, tachypnea, and tachycardia is visible only in large vessels. If a wounded person has bled out, then there is no presence of the swollen neck veins, and the person is extremely pail (5).

The estimation whether the wounded person's heart was also affected should be based on the clinical manifestations and the condition of the wound, in other words, whether the wound's direction could 
affect the heart as well. Besides thorax, patient's back, neck, upper abdomen and shoulders should be examined as well. If the wound is bleeding concurrently with the heart beats, then this makes the diagnosis easier. Unfortunately, this sign often does not appear. This only occurs if the direction of the wound is set at an acute angle in relation to the ventricular wall, so when the heart contracts, it narrows or closes the channel of the wound. Blood pressure at the periphery is not measurable, and the pulse can be felt only in large arteries or not even there. Previously described Beck's triad (low arterial blood pressure, increase in the vein pressure and distant, muffled heart sounds) does not have any clinical value (6). All these signs can be masked by blood coagulation in the pleural space, if the gap in pericardium is wide. That prevents the use of tamponade, leads to hemothorax, and shows the signs of bleeding to death. If the central vein pressure constantly increases in the absence of hemothorax and pneumothorax, then pericardial tamponade is possible. The authors noticed the apparent paradoxical phenomenon of artery pressure oscillations in $35 \%$ of the injured people, if it was measurable.

Huge amount of blood which shows the symptoms of hemothorax runs through the large gaps in pericardium into thorax. Sometimes up to 1.51 of blood (or even more) can be lost in just a few minutes (3). Some doctors consider that this gives a patient a chance to reach the hospital alive. In all suspicious cases, especially in severely wounded patients, pericardiocentesis, which temporarily can be therapeutic, should be carried out (7). It is simple, easi to perform conductible and does not require special conditions, only a few instruments. Unfortunately, in $1 / 5$ of cases it has a negative outcome even when there is a tamponade. The procedure is carried out at two sites, in the left parasternal area, or, more often, in the left paraxiphoid area, at a $45^{\circ}$ angle and aiming the needle toward the right shoulder. Once the blood is drained, the condition of the patient should improve, but the needle should stay inserted until the patient is transferred to the operating room. Positive centesis is a proof of the accuracy of diagnosis and the surgery should begin as soon as possible. The rule "it is better to open and see, then wait and see" applies better here then in some other fields of medicine.

Treatment of contusions consists of clinical control and cardiac support. In case of injuries of the necrotic part, the clinical presentation is the same as in the event of a penetrating trauma. The number of patients who survive these conditions is low. Wounds of the heart valves and papillary muscles are in the domain of cardiac surgery and they exceed the possibilities of general surgical departments. Fortunately, the majority of these patients will live enough to receive this kind of help.

Treatment of penetrating wounds of heart cavities is exclusively surgical.

Eighty percent of patients survive, and according to some authors, even $98 \%$ (6).

\section{EXAMINEES}

During the war in Bosnia and Herzegovina in 1992-1995, the authors worked as surgeons in several mobile war hospitals and mobile surgical teams in Sarajevo, its surroundings as well as in the south-east part of Bosnia. In that period, they or their fellow doctors treated 13 penetrating cardiac wounds, in 12 soldiers and one little girl. The number of contusions is not certain because these patients were treated at internal departments. Out of all 13 cases, three patients were treated in hospitals in Sarajevo and Foča, and other 1o in improvised war hospitals or by mobile surgical teams.

Ten out of 13 patients were immediately operated after perycardiocentesis, one surgery was postponed, and one surgery was a non-cardiac surgery.

Heart perforation was localized in the right ventricle in five cases, in the left in four cases, in the right atrium in three and in the left atrium in one case. Basically, one wound was tangential, without opening the ventricles, so it was not possible to determine which part was more affected. The little girl had heart wounds in both open ventricles, and after the wound was sutured, she died due to the wound of the lower vena cava. That was the only case with death outcome.

The other two cases were specific ones. One soldier had a severe arrhythmia and a shadow of a foreign metal object which moved along with heart beats. Later on, the metal shrapnel was removed from the ventricle compartment in another hospital (cardiac surgery).

The other case, also specific, was treated as massive hemothorax, and drainage was carried out. In this man's thorax there was a visible metal foreign object. After he was discharged from hospital, he had a training (he was a top athlete in the former 
Yugoslavia in his discipline), after which he suffered from a severe pain in his lower leg. An x-ray found a bullet in his knee pit which could not be found in the thorax any more. After reconstructing prior events, it was concluded that this was a case of penetrating wound of the left ventricle, and the metal object moved due to the physical activity. It proves that the ventricle wound can heal spontaneously. A similar thing happened to the soldier who had shrapnel in the ventricle wall. The case with tangential wound of anterior heart surface is also a specific one. Relapsing hemorrhages induced a surgery, and a wound channel which affected the anteriorheart wall, was found without opening the cavities. Ten injured people were immediately operated, two afterwards, and one did not have a heart but a popliteal vein surgery. Pericardiocentesis was carried out in all these patients except for a little girl who died, and all operations had positive outcome. The authors did them paraxiphoidally, and did not encounter any signs of complications caused by this intervention.

The authors opened the thorax using a left thoracotomy through the $4^{\text {th }}$ inter-rib space, and the pericardium in front of the frenicules laterally, without lifting the tip of the heart. Then they put their fingers in the wounds to stop bleeding, and sutured them with monofilament propylene and polyester stitches. Sometimes, they used the material they had at their disposal at that time, and did not encounter any signs of complications caused by the suturing material.

The authors explored the whole surface of the heart and sutured the wound right besides its edge, embracing the entire bulk of the wound's wall. They did not encounter any injuries of coronary arteries. They thoroughly flushed pericardial cavity using warm ph. saline, and during the surgery they had two fibrillations which calmed down soon afterwards.

The authors consider the dead girl's case, the case of the bullet in the left ventricle, shrapnel in the muscular compartment and the tangential cardiac wound to be very rare. Something like this had never been described in the literature available to us.

The number of contusions and their prognosis are not available to us, because they were treated by other doctors in other hospitals.

The number of death outcomes in our group is small. There was only a case of a little girl who died at the operating table. We were also not informed about any possible complications as the other patients we treated had already returned to their homes.

\section{CONCLUSIONS}

It is not possible to make valid conclusions based on such a small number of cases. Nevertheless, it is useful to point out that the destiny of wounded people depends solely on the time when the wounds were inflicted and the time of surgery. The cases that the authors presented had good prognoses due to the fact that the mobile war hospitals or surgical teams were close to the front lines, the units had good transport vehicles and solid first aid was provided. There is no point in wasting time to perform long examinations. It is enough to use only physical methods which can be easily and quickly conducted in a variety of situations. The authors' experience, even though not broad, still confirms a well known truth: "the best provider is the one who provides fast". 


\section{References}

1. Vraneš M. "Povrede Srca". U. Nedeljković I Kanjuh I. Vukotić M.: Kardiologija "Beograd", Beograd 2000. 1751/1756.

2. Vuković M. "Traumatologija". Zavod za udžbenike i nastavna sredstva, Istočno Sarajevo 2009.

3. Patel I. "Traumatology". Masson 4 edd. Paris, Milano 1988.

4. Jablanov J. "Povrede srca u miru i ratu". Kardiologija "Beograd", Beograd 2000. 17561760.
5. Evans J, Gray L, et al. "Principles of Management Cardiac wounds".

6. Kenet VV, Kenet MA. "The heart. In Current therapy of Trauma". Toronto 1986, 249-255.

7. Wiener S.J., Baret J.: Trauma Management for Civilian and Military Physicians. W.B. Saunders Comp. 1989. 


\title{
Ratne povrede srca
}

\author{
Slavko Ždrale, Marko Vuković \\ Hirurška klinika, Klinički centar Istočno sarajevo, Bosna i Hercegovina
}

\section{SAŽETAK}

Rad obrađuju ratne povrede srca, $i$ to kontuzione i penetrantne.Autori iznose svoje iskustvo sa trinaest slučajeva penetrantnih povreda, od kojih su samo dvije lječene u uslovima povoljnim za hirurgiju. Ostalih jedanaest su liječeni u ratnim, uglavnom improvizovanim bonicama i mobilnim hirurškim ekipama. Opisane su osnovne isključivo fizikalne metode pregleda i istaknuto da je"bolje otvoriti pa vidjeti nego čekati pa vidjeti". Takav postupak je dao rezultate uporedive s najboljim u literaturi (samo jedna smrt). Opisana su tri uslovno rečeno specifična slučaja. Jedna tangencijalna povreda s recidivirajućim izlivom i dvije spontano sanirane povrede praćene drugim komplikacijama.

Ključne reči: ratna rana srca, tamponada perikarda, urgentna intervencija 